\section{Containing SARS-CoV-2 in Belize}

Kyle A. Habet MD ${ }^{1,2}$ Diomne Habet $\mathrm{BA}^{3}$ Gliselle Marin, $\mathrm{MConBio}^{4}$

1. Washington University of Health and Science, Ambergris Caye, Belize

2. Belize International Institute of Neuroscience

3.Information Officer, Government of Belize Press Office

4. University of Belize Environmental Research Institute

\section{Correspondence to:}

Dr. Kyle A. Habet

Washington University of Health and Science,

Ambergris Caye, Belize

Email:kyle.h94@gmail.com

\section{Abstract}

Belize is a small Caribbean country in Central America with limited resources in public health. Amidst a global pandemic, urgent attention was given to mitigating the spread of SARS-CoV-2 (COVID-19) in order to prevent a public health catastrophe. Early intervention on a national level was key to preventing the importation of cases and subsequent community transmission. Limiting the conglomeration of people, implementation of curfews, closures of school and universities, governmentmandated social distancing, and extensive contact tracing may have mitigated the exponential spread of COVID-19.

Mandatory mask-wearing in public may have helped to prevent spread between asymptomatic carriers to susceptible individuals. A low population density may have also contributed to containing the virus.

Keywords: Epidemiology, Public Health, Central America, Caribbean, Coronavirus, COVID-19

\section{OVERVIEW}

The information gathered in this article includes official press releases from the Government of Belize, statistics from the Ministry of Health's website, and internet searches on Pubmed and the World Health Organization.

Belize has a population of approximately 408, 000 people. ${ }^{1}$ It consists of six districts and over 200 islands, including three island municipalities. The first confirmed case of SARS-Co-V-2 (COVID-19) was diagnosed in Belize on March $23^{\text {rd }}$ 2020. However, anticipatory measures to mitigate the spread of the virus were taken before the first case was confirmed. ${ }^{2}$

During the outbreak, drastic measures were taken to prevent exponential spread of the virus. These measures are described below. The first confirmed case of COVID19 was on March $23^{\text {rd }}, 2020 .^{3}$ On April $14^{\text {th }}$ the last confirmed positive case was reported. After 20 days with no new confirmed cases, the economy was reopened. The reopening was not a complete return to normal because mask-wearing in public and social distancing guidelines were enforced by law. Belize reached zero active cases on May $5^{\text {th }} 2020$.

The World Health Organization has outlined six guidelines to transitioning to and maintaining a steady state of lowlevel or no transmission in its Strategy Updates. ${ }^{4}$ Many of the recommendations in the WHO's plan were implemented by Belize and may have led to a successful handling of the pandemic in the country.

\section{PRECAUTIONARY MEASURES: PRE-COVID-19 OUTBREAK}

As early as January 2020 a partnership between the government and the private sector was established to refurbish a medical ward in the Karl Heusner Memorial Hospital, Belize's largest public hospital, for the purpose of using it as a COVID-19 isolation unit. The National Oversight Committee co-chaired by the Prime Minister and the Leader of the Opposition Party was assembled to implement precautionary measures. These measures were adopted with bipartisan endorsement, which may have combatted any unwillingness to cooperate by the general public due to political biases. ${ }^{5,4}$

The National Oversight Committee made final decisions 
based on advice from the task force, a group of advisors representing each sector in Belize. Belize took its first step to mitigate the spread of COVID-19 on March $13^{\text {th }}$ and suspended global cruise services for 30 days. ${ }^{7}$ On March $16^{\text {th }}$, seven days before the first case of COVID-19 was confirmed in Belize, further precautionary measures were announced. Persons who were travelling from countries where COVID-19 was endemic were prohibited entry into Belize. Belizean nationals returning to the country from areas of native spread were urged to selfquarantine for 14 days. Social gatherings were limited to 100 people. Ports of entry on the ground were also closed except for cargo. ${ }^{5}$ Campaigns were conducted countrywide to educate the public on the importance of proper hand-washing hygiene and cough and sneeze etiquette. Recommendations were issued to the general public that rely on public transportation to avoid overcrowded buses and employers were instructed by the government to be accommodating to their employees with working hours, as the situation evolved.

All forms of public transportation were mandated to disinfect all vessels following each run. ${ }^{8}$ As cases began to appear throughout Central America, social gatherings were further reduced from 100 to 25 people, including supermarkets, grocery stores, restaurants and bars. ${ }^{2}$ These mandates were heavily imposed by law enforcement.

\section{COVID-19 OUTBREAK PHASE}

On March $23^{\text {rd }}$ the Ministry of Health announced the first confirmed case of COVID-19 in Belize, identified in a female patient living on Ambergris Caye, the country's most populated island with approximately 16,000 people. On that same day, a state of emergency was declared on the island which grounded all vessels entering or leaving Ambergris Caye for 72 hours. During this time the Ministry of Health conducted a mapping and tracing exercise of contacts. ${ }^{9,3}$ Contact tracing of this patient resulted in the detection of one more additional confirmed case. ${ }^{10}$

Ambergris Caye does not have a public hospital. Both patients were placed under mandatory quarantine and allowed to recover at home while being monitored closely by health officials. Residents on the island were encouraged to stay at home and not leave except in the case of unavoidable circumstances. All bars, restaurants, casinos, clubs, and lounges were ordered to close within two days countrywide. ${ }^{9}$ These measures were set in place to contain the first identified cluster of COVID-19. The cases on Ambergris Caye did not require hospitalization in mainland Belize.

In preparation for a potential health crisis, a brigade of Cuban medical professionals specialized to assist in times of disaster and pandemics arrived two days after the first case of COVID-19 was confirmed. ${ }^{11}$ The Judiciary of Belize closed all criminal cases being tried by the Supreme Court and excused all jurors. Civil and family court cases were addressed by written submissions and over the telephone. Where persons had to attend court in person, the guidelines with regards to gatherings and social distancing were enforced. ${ }^{12}$

On March $29^{\text {th }} 2020$ the third confirmed case was identified on mainland Belize. The patient was placed into self -isolation and a mapping exercise of the patient's contacts was conducted. ${ }^{13}$ This led to the declaration of a national state of emergency which included a curfew from 5:00 a.m. to 8:00 p.m. that restricted movement, except for health emergencies. ${ }^{14} \mathrm{~A}$ heavy monetary penalty or two years imprisonment was enforced for anyone who did not adhere to the curfew. Social gatherings were limited to ten persons along with the closure of all services deemed non-essential.

Measurements were implemented on the basis of evidence gathered from other countries and the advice from local experts. The agreed upon conclusion was that the best way to at least slow, and hopefully stop, the spread of the virus, was by strictly enforcing physical distancing, restricting movement of non-essential workers across district lines, quarantining, and self-isolation of COVID-19 patients. ${ }^{14,15}$

Services deemed essential were allowed to operate during the business hours of 5:00 a.m. to 7:00 p.m. Public social distancing of three feet was enforced. Working from home was strongly encouraged wherever possible and social gatherings were prohibited with the exception of funerals capped at a maximum of ten persons. Movement across district boundaries was restricted except for essential workers and it was announced that even Belizean nationals were not allowed entry into the country. ${ }^{16,17}$

On April $7^{\text {th }}$ additional measures were implemented to quarantine the Cayo district where a potential second 
cluster of infections had been identified. ${ }^{18}$ This included restricted movement in and out of the district and reduced working hours for essential services from 8:00 a.m. to $4: 00$ p.m. ${ }^{19}$ Additional legislation prohibited movement across district lines. ${ }^{20}$ On April $17^{\text {th }}$ movement on Sundays was completely restricted for a period of 14 days, except for essential workers and emergencies. ${ }^{21}$

\section{PLATEAU AND RECOVERY PHASE: RETURNING TO}

\section{A NEW NORMAL}

On April $18^{\text {th }} 2020$ Belize plateaued at 18 confirmed cases

(Figure 1.1). Daily public briefings were made on social media, the Government's platform of choice, and other news outlets. As regulations were subsequently slowly lifted, movement of people was allowed on Sunday and non-essential businesses such as hotels and hair salons were allowed to operate within specified protocols to limit social contact. ${ }^{22}$

Despite no new cases, on April $30^{\text {th }}$, it was made mandatory for all citizens to wear face masks in public. Businesses that were allowed to reopen were instructed to ensure a distance of at least six feet between employees. Furthermore, all employees were required to wear masks. Certain establishments remained closed including casinos, gaming establishments, gymnasiums, sporting complexes, discotheques, bars and nightclubs. A curfew remained active between the hours of 5:00 a.m. to 8:00 p.m. for non-essential workers. Movement during

Fig 1 Number of confirmed cases (red line), new cases (blue vertical bars) and active cases (green line) of Coronavirus Disease 2019 in Belize from March $12^{\text {th }}$ to May $8^{\text {th }}$ with measures taken (numbers) by the Government over time.

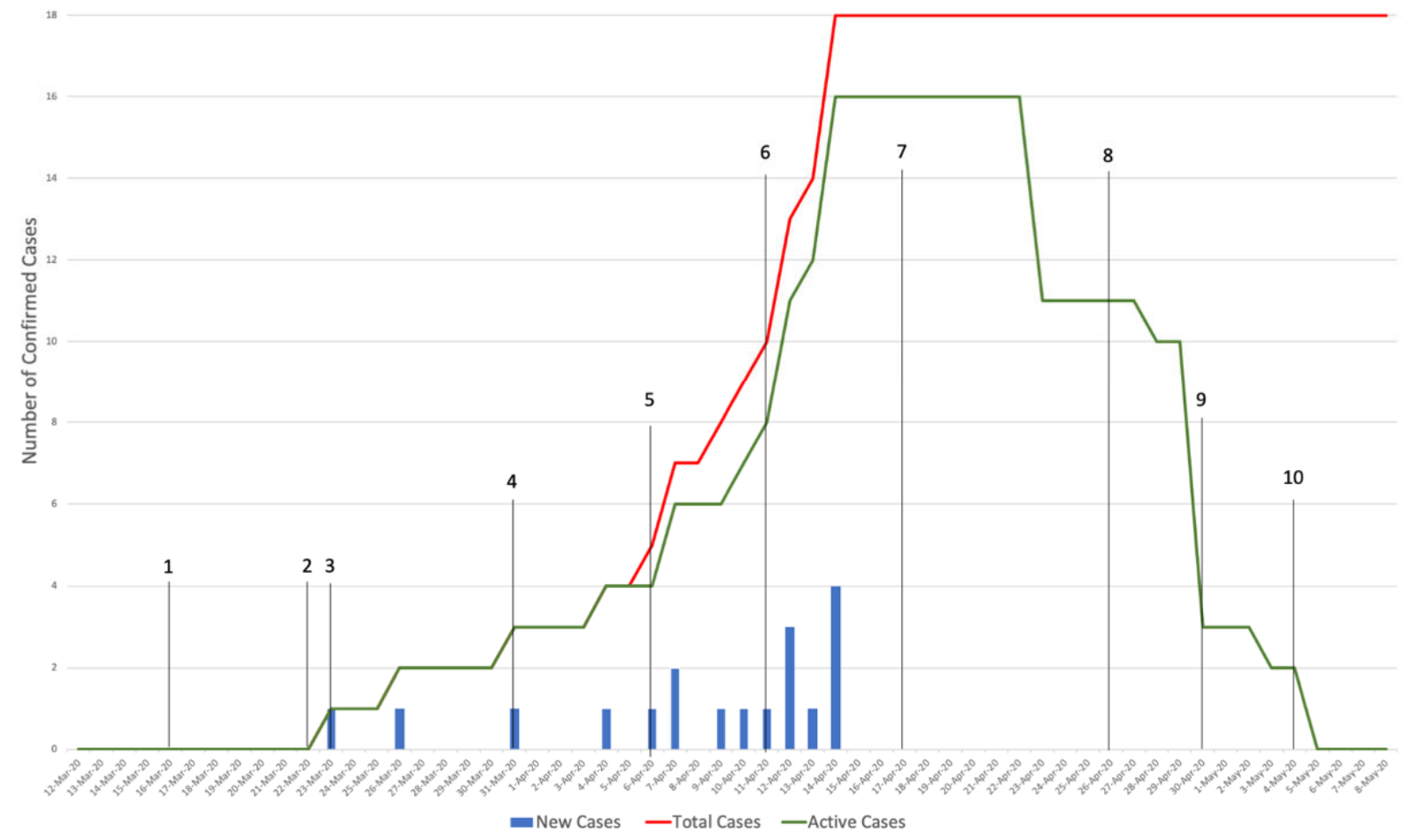

1. Announcement to close schools, daycares and universities $^{6}$

2. Announcement to close the international airport ${ }^{3}$

3. Quarantine of Ambergris Caye ${ }^{9}$

4. Declaration of national state of emergency and curfew ${ }^{13}$

5. Belizean nationals prohibited entry to Belize, quarantining of Cayo district ${ }^{15,17}$
6. Movement across district lines prohibited ${ }^{19}$

7. Total Sunday Lockdown ${ }^{20}$

8. Total Sunday Lockdown lifted ${ }^{21}$

9. Gradual reopening, mandatory mask-wearing ${ }^{24}$

10. Most businesses allowed to open, schools and borders remain closed $^{22,23}$ 
non-curfew hours had to be purposeful and all citizens were subject to questioning by law enforcement officers when outside. Social distancing and sanitization continued to be enforced and encouraged.

On May $4^{\text {th }} 2020$, new legislation was signed into effect to allow almost all businesses to reopen with the exception of schools and daycare centers. ${ }^{23}$ Belize's largest industry, the tourism sector, suffered the most significant economic impact when all borders were closed. The indefinite closure of the tourism industry by COVID-19 made reopening the local economy a priority. Social distancing protocols remained enforced with an emphasis on wearing face masks, regularly sanitizing hands and maintaining a six-foot distance in between patrons. A strict curfew and restriction on movement across district lines remained in place to minimize unnecessary movement. ${ }^{24}$

On May $5^{\text {th }} 2020$ the number of active cases in Belize reached zero. The total number of cases between March $23^{\text {rd }}$ and May $5^{\text {th }}$ was 18 with a male to female ratio of $1: 1$. The total number of deaths was two with the total number of tests equaling 1,128 on May $5^{\text {th }}$.

\section{CURRENT SITUATION AND FINAL THOUGHTS}

COVID-19 has an incubation period of up to 14 days and may be asymptomatic in some individuals. ${ }^{25,26}$ This characteristic makes it challenging to detect and isolate asymptomatic patients and patients in the incubation phase who are potentially infectious. ${ }^{27}$ For this reason, closure of schools and universities as well as limiting social gatherings before any cases of COVID-19 were confirmed may have played a major role in minimizing or eliminating spread between asymptomatic or patients during the incubation period.

During the outbreak phase, GOB enforced draconian measures to enforce physical distancing and limiting movement of people which may have mitigated community spread. After the first case of COVID-19 was confirmed on Ambergris Caye, the entire island was quarantined and placed under a state of emergency. After the third confirmed case was identified, the entire country was placed under a state of emergency. When clusters were identified in Cayo, the entire district was also quarantined and movement between district lines was prohibited by non-essential workers. ${ }^{18}$ In every instance, contact tracing was conducted and self-isolation of contacts was mandatory.

The closure of borders and non-essential businesses had a major impact on the livelihoods of many Belizeans. Government initiatives and assistance received from the international community aimed to alleviate the hardships created by the unemployment and loss of the tourism industry. ${ }^{28,29}$ Additional aid came in the form of donations of personal protective equipment for frontline workers, food, monetary donations and human resources from other countries. ${ }^{11,28,30}$ Without aid, increased pressure from the general public due to economic hardship might have led to a premature opening of the economy and a decrease in community engagement.

Early intervention on a national level was key to preventing importation of cases and subsequent community transmission. Regulations limiting the conglomeration of people, curfews, closures of school and universities and government-mandated social distancing, and extensive mapping of the three main clusters of COVID-19 identified in the country are all factors which may have mitigated the exponential spread of COVID-19. Only symptomatic patients and those in close contact with confirmed COVID-19 patients were tested; as such, many asymptomatic infections may have been undiagnosed. However, early interventions restricted movement across district borders and physical distancing contributed to the control of the spread of COVID-19.

Mandatory mask-wearing in public in the absence of new cases for 18 days may have helped to eliminate the virus from the country by preventing the spread of the virus from asymptomatic or minimally symptomatic carriers to susceptible individuals. On May $5^{\text {th }} 2020$ there were no active cases in Belize. The measures taken by the National Oversight Committee were based on data from other countries and the advice of local experts on the task force. Belize met all measurable guidelines outlined by the WHO for transitioning to and maintaining a steady state of low-level or no transmission on May $4^{\text {th }}$ when most businesses were allowed to reopen (Table 1).

Another major factor that may have contributed to the mitigation of the spread of COVID-19 is the low population density of Belize (16.79 people per $\left.\mathrm{km}^{2}\right){ }^{31}$ The exact specificity and sensitivity of the deep nasopharyngeal swab RT-PCR test for SARS-CoV-2 was unknown at the time of this study. Testing continued 
Table 1 The World Health Organization's guidelines for transitioning to and maintaining a steady state of low-level or no transmission compared with the situation in Belize on May $4^{\text {th }} 2020$, when most businesses were allowed to reopen

\begin{tabular}{|c|c|}
\hline WHO Guidelines $^{5}$ & Situation in Belize on May $4^{\mathrm{th}}, 2020$ \\
\hline $\begin{array}{l}\text { COVID-19 transmission is controlled to a level of } \\
\text { sporadic cases and clusters of cases, all from } \\
\text { known contacts or importations and the incidence } \\
\text { of new cases should be maintained at a level that } \\
\text { the health system can manage with substantial } \\
\text { clinical care capacity in reserve. }\end{array}$ & $\begin{array}{l}\text { No new cases for } 20 \text { days. Contact tracing } \\
\text { exercises were carried out for each positive case. }\end{array}$ \\
\hline $\begin{array}{l}\text { Sufficient health system and public health } \\
\text { capacities are in place to enable the major shift } \\
\text { from detecting and treating mainly serious cases } \\
\text { to detecting and isolating all cases, irrespective of } \\
\text { severity and origin: } \\
\text { Detection: suspect cases should be detected } \\
\text { quickly after symptom onset through active case } \\
\text { finding, self-reporting, entry screening, and other } \\
\text { approaches; }\end{array}$ & $\begin{array}{l}\text { Total Cases in Belize was } 18 \text { and the public health } \\
\text { system never reached a point of saturation. Most } \\
\text { cases were monitored from home. Hotlines were } \\
\text { made available in case patients deteriorated. }{ }^{20}\end{array}$ \\
\hline - Testing & $\begin{array}{l}\text { Testing was done were cases were suspected. } \\
\text { Asymptomatic individuals were tested when a } \\
\text { history of close contact with a positive case was } \\
\text { identified. }\end{array}$ \\
\hline - Isolation & COVID-19 isolation units available. \\
\hline - Quarantine & $\begin{array}{l}\text { Patients with a suspected case of COVID-19 are } \\
\text { mandated to self-quarantine until results are } \\
\text { negative. Positive results are mandated to self- } \\
\text { quarantine until recovered (defined as a negative } \\
\text { test result)14 }\end{array}$ \\
\hline $\begin{array}{l}\text { Outbreak risks in high-vulnerability settings are } \\
\text { minimized }\end{array}$ & $\begin{array}{l}\text { No outbreaks occurred in high-vulnerability } \\
\text { settings such as schools, prisons or nursing } \\
\text { homes documented. }\end{array}$ \\
\hline Workplace preventive measures are established & $\begin{array}{l}\text { The provisions of Statutory Instrument } 66 \text { lay out } \\
\text { strict social distancing guidelines for workers and } \\
\text { employees, instruct that hand sanitizer be } \\
\text { available to all employees and directs the general } \\
\text { public to wear a facemask at all times when not } \\
\text { indoors. }\end{array}$ \\
\hline Risk of imported cases managed & $\begin{array}{l}\text { Boarders remained closed. Automatic } \\
\text { imprisonment was the penalty for entering Belize } \\
\text { illegally even for Belizean nationals. }\end{array}$ \\
\hline Communities are fully engaged & $\begin{array}{l}\text { The level of community engagement could not be } \\
\text { objectively measured. }\end{array}$ \\
\hline
\end{tabular}

after zero active cases were reported including random testing. On June $5^{\text {th }} 2020$ (53 days after the last confirmed case) the $19^{\text {th }}$ confirmed case of COVID-19 was detected in Belize. The patient was an asymptomatic, repatriated citizen undergoing routine testing during mandatory quarantine after returning from a cruise ship. $^{32}$ Contact tracing is underway and the due process of informing the cruise ship and relevant counterparts has begun. To this date, all borders remain closed and only flights carrying repatriated citizens are allowed entry. Schools and daycare centers remain closed. Continued assistance is being received internationally and 
unemployment relief programs are ongoing. ${ }^{33,34} \mathrm{~A}$ preexisting Food Pantry Program was extended and the Food Assistance Program was created to alleviate the economic hardship experienced by Belizeans. ${ }^{35}$

Ethical Approval Statement: not applicable

Conflict of interest statement: none to declare

\section{Funding statement: none}

Author Contributions: Dr. Kyle Habet wrote the majority of the manuscript. Diomne Habet contributed by proofreading the manuscript and verified that all information was accurate. She also wrote text for all subheadings of the manuscript. Gliselle Marin wrote most of the "Plateau and Return to New Normal" section, proofread and was involved in drafting the format of the manuscript.

\section{REFERENCES}

1. Statistical Institute of Belize. Statistical Institute of Belize. http://sib.org.bz/ (Accessed 04/05/2020)

2. New Measures Announced to Protect Against COVID19 - Government of Belize Press Office.https:// www.pressoffice.gov.bz/new-measures-announced-to -protect-against-covid-19/ (Accessed 11/04/2020)

3. Ministry of Health Announces First Case of COVID-19 - Government of Belize Press Office. https:// www.pressoffice.gov.bz/ministry-of-health-announces -first-case-of-covid-19/ (Accessed 11/04/2020).

4. Transitioning to and maintaining a steady state of low -level or no transmission. https://www.who.int/ thailand/news/detail/18-04-2020-transitioning-to-and -maintaining-a-steady-state-of-low-level-or-notransmission (Accessed 06/06/2020)

5. Belize Announces New Measures in Response to COVID-19 - Government of Belize Press Office. Published 2020. https://www.pressoffice.gov.bz/ belize-announces-new-measures-in-response-to-covid -19/ (Accessed 11/04/2020)

6. Closure of Daycare Centers - Government of Belize Press Office. Published 2020. https:// www.pressoffice.gov.bz/closure-of-daycare-centers/ (Accessed 11/04/2020)
7. Postponement of Cruise Line Service to Belize as Precautionary Measure amid COVID-19 Government of Belize Press Office. https:// www.pressoffice.gov.bz/postponement-of-cruise-lineservice-to-belize-as-precautionary-measure-amidcovid-19/(Accessed 10/06/2020)

8. Public Transportation Protocol for COVID-19Government of Belize Press Office. Published 2020. https://www.pressoffice.gov.bz/public-transportationprotocol-for-covid-19/ (Accessed 11/04/2020)

9. State of Emergency Declared for Ambergris Caye Government of Belize Press Office. https:// www.pressoffice.gov.bz/state-of-emergency-declared -for-ambergris-caye/ (Accessed 08/04/2020)

10. COVID-19 Test Samples - Update No. 1. Published 2020. http://health.gov.bz/www/component/content/ article/177-general-health/1029-covid-19-testsamples--update-no-1 (Accessed 23/04/2020)

11. Cuban Medical Professionals Help Belize Fight COVID19 - Government of Belize Press Office.https:// www.pressoffice.gov.bz/cuban-medical-professionalshelp-belize-fight-covid-19/ (Accessed 08/04/2020)

12. The Judiciary of Belize - Response to COVID-19 Preventative Measures - Government of Belize Press Office. https://www.pressoffice.gov.bz/the-judiciaryof-belize-response-to-covid-19-preventativemeasures/ (Accessed 08/04/2020)

13. Ministry of Health Confirms Third Case of COVID-19 in Belize - Government of Belize Press Office. https:// www.pressoffice.gov.bz/ministry-of-health-confirmsthird-case-of-covid-19-in-belize/ (08/04/2020).

14. Prime Minister Rt. Hon. Dean Barrow Announces Countrywide State of Emergency - Government of Belize Press Office. https://www.pressoffice.gov.bz/ prime-minister-rt-hon-dean-barrow-announcescountrywide-state-of-emergency/(Accessed 22/04/2020).

15. How To Self Isolate - Government of Belize Press Office. https://www.pressoffice.gov.bz/how-to-selfisolate/ (Accessed 07/05/2020).

16. All Borders Closed to the Entry of Belizean Nationals - Government of Belize Press Office. Published 2020. https://www.pressoffice.gov.bz/all-borders-closed-tothe-entry-of-belizean-nationals/ (Accessed 
07/05/2020)

17. Belize Constitution. Belize Constitution. Statutory Instrument No 47 of 2020, (Emergency Powers) (Amendment) Regulations, 2020.; 2020.

18. Prime Minister Announces Lockdown of Cayo District and Additional Nationwide Measures - Government of Belize Press Office. https://www.pressoffice.gov.bz/ prime-minister-announces-lockdown-of-cayo-districtand-additional-nationwide-measures/ (Accessed 07/05/2020)

19. Belize Constitution. Belize Constitution. Statutory Instrument No 52 of 2020, (Emergency Powers) (Amendment) (No. 3) Regulations, 2020.; 2020.

20. Belize Constitution. Belize Constitution. Statutory Instrument No 54 of 2020, (Emergency Powers) (Amendment) (No. 4) Regulations, 2020.; 2020.

21. Belize Constitution. Belize Constitution. Statutory Instrument No 55 of 2020, (Emergency Powers) (Amendment) Regulations, 2020.; 2020.

22. Prime Minister Rt. Hon. Dean Barrow Updates the Nation on the Existing State of Emergency Government of Belize Press Office. https:// www.pressoffice.gov.bz/prime-minister-rt-hon-deanbarrow-updates-the-nation-on-the-existing-state-ofemergency/ (Accessed 07/05/2020).

23. Belize Constitution. Statutory Instrument No 66 of 2020, (Emergency Powers) (Amendment) Regulations, 2020. https://www.pressoffice.gov.bz/ wp-content/uploads/2019/12/SI-No-66-of-2020.pdf

24. Belize Constitution. Belize Constitution. Statutory Instrument No 67 of 2020, (Emergency Powers) (Amendment) (No.2) Regulations, 2020. https:// www.pressoffice.gov.bz/wp-content/ uploads/2019/12/SI-No.-67-of-2020.pdf

25. Guan W, Ni Z, Hu Y, et al. Clinical Characteristics of Coronavirus Disease 2019 in China. N Eng/ J Med. Published online February 28, 2020. doi:10.1056/ NEJMoa2002032

26. Belize Constitution. Belize Constitution. Statutory Instrument No 65 of 2020, (Emergency Powers) Regulations, 2020. https://www.pressoffice.gov.bz/ wp-content/uploads/2019/12/SI-No-65-of-2020Belize-Constitution-1.pdf
27. Yu P, Zhu J, Zhang Z, Han Y, Huang L. A familial cluster of infection associated with the 2019 novel coronavirus indicating potential person-to-person transmission during the incubation period. J Infect Dis. Published online February 18, 2020. doi:10.1093/ infdis/jiaa077

28. COVID-19 eServices Citizens Portal for Unemployment Relief Program - Government of Belize Press Office. https://www.pressoffice.gov.bz/ covid-19-eservices-citizens-portal-for-unemploymentrelief-program/ (Accessed 06/05/2020).

29. Hotline \& Focal Point For Covid-19 (Ministry Of Health) - Government of Belize Press Office.. https:// www.pressoffice.gov.bz/hotline-focal-point-for-covid19-ministry-of-health/ (Accessed 07/05/2020)

30. UNICEF Scales Up Support to Belize Ministry of Education's School Feeding Program during COVID19 Pandemic - Government of Belize Press Office. https://www.pressoffice.gov.bz/unicef-scales-upsupport-to-belize-ministry-of-educations-schoolfeeding-program-during-covid-19-pandemic/ (Accessed 06/05/2020)

31. Population density (people per sq. km of land area) Belize | Data. Accessed May 4, 2020. https:// data.worldbank.org/indicator/EN.POP.DNST? locations $=\mathrm{BZ}$

32. Ministry of Health Confirms 19th Case of COVID-19 Government of Belize Press Office.. https:// www.pressoffice.gov.bz/ministry-of-health-confirms19th-case-of-covid-19/ (Accessed 05/06/2020)

33. Taiwan Donates 15,000 Masks and Temperature Measurement System to the Ministry of Foreign Affairs - Government of Belize Press Office. https:// www.pressoffice.gov.bz/taiwan-donates-15000-masks -and-temperature-measurement-system-to-theministry-of-foreign-affairs/ (Accessed 06/06/2020).

34. Update on Unemployment Relief Program Government of Belize Press Office. Accessed June 6, 2020. https://www.pressoffice.gov.bz/update-onunemployment-relief-program-3/

35. New Food Pantry Schedule - Government of Belize Press Office. Accessed June 6, 2020. https:// www.pressoffice.gov.bz/new-food-pantry-schedule/ 